\title{
ANALISIS PERKEMBANGAN ANAK USIA DINI DENGAN MODEL DDST II DI SEKOLAH ALAM INDONESIA PALEMBANG
}

\section{ANALYSIS OF DEVELOPMENT OF EARLY AGE CHILDREN WITH DDST II MODEL IN THE INDONESIA NATURAL SCHOOL OF PALEMBANG}

\author{
${ }^{1}$ Azwaldi, ${ }^{2}$ Hanna Dl Damanik, ${ }^{3}$ Imelda Erman \\ ${ }^{1,2,3}$ Politeknik Kesehatan Kementerian Kesehatan Palembang \\ Program Studi Diploma IV Keperawatan \\ e-mail : azwaldi03@gmail.com
}

\begin{abstract}
ABSTRAK
Perkembangan merupakan hasil interaksi kematangan susunan saraf pusat dengan organ yang dipengaruhinya sehingga perkembangan ini berperan penting dalam kehidupan manusia.Anak-anak yang dalam masa pertumbuhan dan perkembangan memiliki rasa keingintahuan yang besar terhadap lingkungan sekitar. Penelitian bertujuan mengetahui Perkembangan Anak Usia Dini dengan Model DDST II Di Sekolah Alam Indonesia Palembang. Metode; Desain penelitian ini dilakukan menggunakan pendekatan kuantitatif dengan desain penelitian Cross secsional terhadap variabel penelitian. Besar sampel adalah 30 responden dengan teknik Total Quota Sampling. Untuk analisisnya menggunakan uji chi-square test dengan derajat kemaknaan $\alpha=0,05$. Hasil penelitian menunjukan ada hubungan signifikan antara variabel status social ekonomi orang tua dengan tingkat perkembangan anak dengan nilai p-Value sebesar pValue $=0,01$, untuk hubungan variabel riwayat Kelahiran dan berat badan lahir dengan tingkat perkembangan anak menunjukkan hubungan yang tidak signifikan dengan nilai $\mathrm{p}$-Value $>\alpha=0,05$ masing-masing $\mathrm{p}$-Value $=0,773$ danpValue $=0,337$, sedangkan variabel penyakit kronis yang pernah diderita tidak dilakukan uji chi square karena tidak ada variasi nilai variabelnya. Kesimpulan; ada hubungan yang bermakna antara status sosial ekonomi orangtua dengan tingkat perkembangan anak Usia dini di sekolah alam Indonesia Palembang. Diharapkan pemahaman orang tua dan masyarakat terhadap proses perkembangan anak usia dini lebih meningkat dan dapat mengenal dengan baik tanda-tanda keterlambatan proses perkembangan anak termasuk faktor yang berpengaruh.

Kata Kunci : Anak Usia Dini, Perkembangan, Sekolah Alam
\end{abstract}

\begin{abstract}
Improvement is a result interaction of central nervous system maturity with the organ affected so the improvement has important role of human life. Childern who are in growth period have a great curiosity for surrounding environment. The research aims to know the improvenent of early childhood by DDST II Model in Indonesia Nature School Palembang. Method; The research design is conducted by using quantitative approach with cross secsional research design of research variables. The samples are 30 respondents with total quota sampling technique. For the analysis uses chi-square test with significance level $a=0,05$. Result; The result showed there was a significant relation between parents socioeconomic status variables with child's improvement level by $\mathrm{p}$-Value of $\mathrm{p}$-Value $=0,01$ for the relation between birth history variable and birth weigh with child improvement level shows unsignificant relation with pvalue \&gt; $\alpha=0,05$, respectively $\mathrm{p}$-value $=0,773$ and $\mathrm{p}$-Value $=0,337$, Conclusions; while the cronic disease variable that have been suffered are not tested for chi square because there's not variable score variation. It is expected parent's and society's understanding of the childhood growth process, increase more and be able to recognize the signs of delays in child growth process including influential factors.
\end{abstract}

Keywords : Early Childhood, Improvement, Indonesia Nature School 


\section{PENDAHULUAN}

Indonesia berada di peringkat ke-101 sebagai negara yang memberi kesempatan bagi tumbuh kembang anak versi lembaga Save The Children alamlaporan Childhood Index 2017.Peringkat tersebut menyimpulkan bahwa tidak sedikit anak di Indonesia kehilangan masa anakanaknya. Di kawasan ASEAN, Indonesia berada di belakang Singapura (peringkat 33), Malaysia (peringkat 65) dan Thailand (peringkat 84) namun masih lebih baik daripada Myanmar (112), Kamboja (117) dan Laos (130) ${ }^{1}$.

Data Badan Pusat Statistik (BPS) pada 2015 menyatakan bahwa angka partisipasi sekolah di Indonesia untuk tingkat SD sebanyak 96,7 persen, SMP sebanyak 77,82 persen dan SMA sebanyak 59,71 persen. Sementara itu, data UNICEF pada 2016 menyebut sebanyak 2,5 juta anak Indonesia tidak dapat menikmati pendidikan dimana sekitar 600 ribu anak sekolah dasar dan 1,9 juta anak pada tingkat SMP. Di Indonesia, pada 2016 sebanyak 44,3 anak masih hidup di bawah garis kemiskinan, anak-anak ini lebih cenderung mengalami berbagai bentuk kemiskinan, terekslusi dari fasilitas layanan dasar dan karena itu lebih cenderung tertinggal di belakang ${ }^{2}$.

Salah satu bentuk sistem pendidikan yang digagas untuk merubah keadaan dunia pendidikan Indonesia saat ini dan mulai dikembangkan di Indonesia adalah pendidikan sekolah alam. Sistem pendidikan sekolah alam ini berbeda dari sekolah formal umumnya. Sekolah Alam merupakan sekolah dengan konsep pendidikan berbasis alam semesta. Dalam pembelajarannya konsep sekolah alam yang dipakai adalah dengan cara belajar sambil bermain dengan harapan orientasi fokusnya mengembangkan kelebihan yang dimiliki anak dengan metode pencarian yang tak baku dan relatif menyenangkan diterima anak dalam bentuk permainan tertentu. Metodologi pembelajaran yang dipakai cenderung mengarah pada pencapaian logika berpikir inovatif yang baik dalam bentuk action learning (praktik nyata) ${ }^{3}$.

Berdasarkan uraian latar belakang diatas pendekatan metode pembelajaran berbasis alam lebih menghasilkan perkembangan yang lebih dibandingkan metode konvensional, sehingga peneliti tertarik untuk meneliti Perkembangan Anak Usia Dini dengan Model DDST II Di sekolah Alam Palembang Tahun 2019

Tujuan dalam penelitian ini adalah untuk mengetahui Perkembangan Anak Usia Dini dengan Model DDST II Di sekolah Alam Palembang Tahun 2019.

\section{METODE}

Penelitian ini menggunakan pendekatan kuantitatif dengan desain observasional analitik dengan pendekatan cross sectional dan diambil secara Total Quota Sampling, dengan Surat persetujuan Komisi etik dari Politeknik Kesehatan Makassar dengan nomor : 1024/KEPK-PTKMKS/VIII/2019 tanggal 7 Agustus 2019

Yang menjadi sampel anak usia dini (4-6 tahun) yang bersekolah di Sekolah Alam Indonesia Palembang, dengan jumlah sampel 30 responden. Variabel independent jenis kelamin, status sosial 
ekonomi, riwayat persalinan, berat badan lahir dan riwayat penyakit kronis serta variabel dependen adalah tingkat perkembangan anak. Instrumen yang digunakan adalah lembar kuesioner, lembar observasi DDST II. Langkahlangkah pelaksanaan pengumpulan data pada responden dilakukan dengan melakukan wawancara pada responden kemudian observasi dan pengukuran terhadap tingkat perkembangan anak.

Pengumpulan data dilakukan dengan teknik wawancara, angket, pengukuran atau observasi. Untuk data data identitas dan jenis kelamin anak diperoleh dari data Sekolah, data social ekonomi orang tua, riwayat persalinan, berat badan lahir dan penyakit kronis yang diderita diperoleh dari angket yang diberikan ke orang tua melalui guru kelas dan data tingkat perkembangan dilakukan observasi dan pengukuran meliputi aspek motorik halus yaitu berupa : Menggambar Tanda Tambah (+), Menggambar Empat Persegi, Menunjuk Garis, aspek motorik kasar berupa : penilaian dengan terhadap tindakan berdiri dengan 1 (satu) kaki, Berjalan dengan tumit kaki, aspek personal sosial berupa : Mengambil Makanan, Berpakaian, Gosok Gigi, Bermain Ular Tangga dan aspek bahasa berupa : menyebutkan kata, mengartikan kata, menyebutkan lawan kata, Kegunaan benda. Hari ketujuh dilakukan penilaian dikelas $\mathrm{B}$ dengan jumlah 11 anak : langkah mengambil kesimpulan terhadap anak adalah dikategorikan normal jika tidak ada keterlambatan/minimal paling banyak satu peringatan /keterlambatan pada anak dan dikategorikan suspect jika ada lebih sama dengan 2 keterlambatan (anak tidak mampu melakukan aktivitas pada aspek aspek perkembangan pada DDST II, dengan 17 item aktivitas dari 4 Aspek yang diukur atau observasi. Diperoleh nilai 8 responden dengan nilai 16,1 responden nilai 10 dan 1 responden dengan nilai 9 sedangkan 20 responden dengan nilai 17 artinya semua aktivitas mampu dilakukan sesuai dengan tingkat perkembangan anak

\section{HASIL}

Berikut ini adalah hasil penelitian :

Tabel 1. Distribusi Karakteristik Responden $\mathrm{N}=30$

\begin{tabular}{|c|c|c|}
\hline Variabel & Jumlah (n) & Persentase (\%) \\
\hline \multicolumn{3}{|l|}{ Jenis Kelamin } \\
\hline Laki-laki & 18 & 60 \\
\hline Perempuan & 12 & 40 \\
\hline \multirow{2}{*}{\multicolumn{3}{|c|}{$\begin{array}{l}\text { Status Sosial } \\
\text { Ekonomi orang } \\
\text { tua }\end{array}$}} \\
\hline & & \\
\hline Kelas Atas & 10 & 33,3 \\
\hline Kelas Menengah & 13 & 43,3 \\
\hline Kelas Bawah & 7 & 23,4 \\
\hline \multirow{2}{*}{\multicolumn{3}{|c|}{$\begin{array}{l}\text { Riwayat } \\
\text { Persalinan }\end{array}$}} \\
\hline & & \\
\hline Normal & 17 & 56,7 \\
\hline Caesar/Tindakan & 13 & 43,3 \\
\hline \multicolumn{3}{|c|}{ Berat Badan Lahir } \\
\hline \multicolumn{3}{|l|}{ Normal } \\
\hline BBLR & 25 & 83,3 \\
\hline & 5 & 16,7 \\
\hline \multirow{3}{*}{\multicolumn{3}{|c|}{$\begin{array}{l}\text { Penyakit Kronis } \\
\text { Yang Pernah } \\
\text { Diderita }\end{array}$}} \\
\hline & & \\
\hline & & \\
\hline \multicolumn{3}{|l|}{ Tidak Pernah } \\
\hline \multirow[t]{2}{*}{ Pernah } & 30 & 100 \\
\hline & 0 & 0 \\
\hline \multirow{2}{*}{\multicolumn{3}{|c|}{$\begin{array}{l}\text { Tingkat } \\
\text { Perkembangan }\end{array}$}} \\
\hline & & \\
\hline \multicolumn{3}{|l|}{ Normal } \\
\hline Suspect & 26 & 86,7 \\
\hline & 4 & 13,3 \\
\hline
\end{tabular}

Tabel 1. Menunjukkan $60 \%$ responden berjenis kelamin laki-laki, 23,4 \% dengan status ekonomi orang tua kelas bawah, 56,7 \% dengan kelahiran 
normal, responden $83,3 \%$ Berat badan lahir normal dan 86,7 \% dengan tingkat perkembangan normal.

Tabel 2. Hubungan Karakteristik dengan tingkat perkembangan anak $\mathrm{N}=30$

\begin{tabular}{|c|c|c|c|c|}
\hline \multirow{3}{*}{ Variabel } & $\begin{array}{r}\mathrm{T} \\
\text { Perk }\end{array}$ & $\begin{array}{l}\text { at } \\
\text { angan }\end{array}$ & \multirow{2}{*}{ Total } & \multirow{3}{*}{$\begin{array}{c}\mathrm{p}- \\
\text { value }\end{array}$} \\
\hline & Normal & Suspect & & \\
\hline & $\%$ & $\mathrm{n} \%$ & $\%$ & \\
\hline
\end{tabular}

\section{Jenis}

Kelamin

$\begin{array}{llllllll}\text { Laki-laki } & 15 & 50 & 3 & 10 & 18 & 60 & 0,511\end{array}$

$\begin{array}{lllllll}\text { Perempuan } & 11 & 36,6 & 1 & 3,4 & 12 & 40\end{array}$

\section{Tingkat}

Sosial

Ekonomi

Orang tua

$\begin{array}{lcllllll}\text { Atas } & 10 & 33,3 & 0 & 0 & 10 & 33,3 & 0,001 \\ \text { Menengah } & 13 & 43,3 & 0 & 0 & 13 & 43,3 & \\ \text { Bawah } & 3 & 10 & 4 & 6,7 & 7 & 23,4 & \end{array}$

\section{Riwayat}

Persalinan

$\begin{array}{llllllll}\text { Normal } & 15 & 50 & 2 & 6,6 & 17 & 56,6 & 0,773\end{array}$

$\begin{array}{lllllll}\text { Caesar/Tin } & 11 & 36,6 & 2 & 6,6 & 13 & 43,4\end{array}$

dakan

Berat

Badan

Lahir

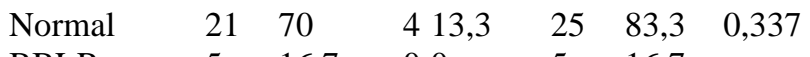

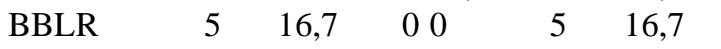

Pada Tabel 2. Memperlihatkan hubungan jenis kelamin dengan tingkat perkembangan bahwa ada 15 dari 18 responden (50\%) anak berjenis kelamin laki-laki dengan tingkat perkembangan normal, sedangkan yang berjenis kelamin perempuan dengan tingkat perkembangan normal 11 dari 12 responden $(36,3 \%)$ dengan nilai $p$ Value $=0,511$, sedangkan hubungan status sosial ekonomi orang tua dengan tingkat perkembangan anak menunjukkan 10 dari 10 responden $(33,3 \%)$ status sosial ekonomi orang tua berada pada kelas atas dengan tingkat perkembangan normal, sedangkan yang kelas bawah dengan tingkat perkembangan normal 3 dari 7 (10\%), dengan nilai $p$-Value $=0,001$, Hasil analisis hubungan riwayat persalinan anak dengan tingkat perkembangan anak menunjukkan bahwa ada 15 dari $17(50 \%)$ riwayat persalinan anak normal dengan tingkat perkembangan normal, sedangkan riwayat persalinan anak Caesar/tindakan dengan tingkat perkembangan normal 11 dari 13 (36,6\%), dengan nilai $p$-Value $=0,773$

Hasil analisis hubungan berat badan lahir dengan tingkat perkembangan anak menunjukkan bahwa ada 21 dari 25 (70\%) berat badan lahir anak normal dengan tingkat perkembangan normal, sedangkan berat badan lahir Rendah dengan tingkat perkembangan normal 5 dari $5(16,7 \%)$. Dengan nilai $p$-Value $=0,337$.

\section{PEMBAHASAN}

Untuk jenis kelamin terkait dengan tingkat perkembangan anak jelas terlihat tidak ada keterkaitannya, hal ini dikarenakan usia responden berada dalam rentang $4-6$ tahun yang belum memasuki masa prapubertas, karena jika responden telah masuk masa prapubertas maka jenis kelamin akan berpengaruh terhadap tingkat perkembangan dimana perempuan mengalami masa prapubertas lebih dahulu dibanding laki-laki, yang pada akhirnya berdampak terhadap tingkat perkembangan anak ${ }^{4}$.

Status sosial ekonomi adalah suatu tingkatan yang dimiliki oleh seseorang yang didasarkan pada kemampuan dalam memenuhi kebutuhan hidup 
sehari-hari dari penghasilan yang diperoleh sehingga mempunyai peranan pada status sosial seseorang dalam struktur masyarakat. Penghasilan atau pekerjaan tertentu juga dapat menentukan tinggi rendahnya status kesehatan seseorang. Secara sederhana status sosial ekonomi adalah status seseorang dalam masyarakat dilihat dari segi pendapatan, kekayaan, dan jabatan. Status sosial ekonomi dikonseptualisasikan sebagai ukuran komposit yang menggabungkan ekonomi seperti keuangan dan kekayaan, manusia seperti pendidikan dan pelatihan, sosial seperti keluarga dan hubungan masyarakat, sumber daya dan perlindungan yaitu modal yang dimana individu atau komunitas memiliki akses untuk bertahan hidup.

Penjelasan diatas menjadi tidak absolut jika dikaitkan dengan asupan energi dan protein pada anak pada masa perkembangan, hal ini dikarenakan status social ekonomi yang baik belum tentu menjamin asupan energi dan protein yang baik juga pada anak.

Asupan energi dan protein yang rendah berdampak pada meningkatnya resiko masalah gizi seperti kekurangan energi kronis dan kekurangan energi protein, selain pada balita dapat berdampak pada terhambatnya pertumbuhan dan perkembangan kognitifnya ${ }^{5}$.

Upaya mengoptimalkan perkembangan anak dituntut kerjasama yang baik antar pendidik dan orang tua dengan pemahaman yang benar dan tepat terkait perkembangan anak sehingga gangguan perkembangan pada tingkat dini dapat dideteksi secara cepat dengan dampak minimal
Pemahaman yang baik tentang perkembangan anak bagi pendidik dan orang tua akan sangat membantu dalam memberikan stimulasi/ rangsangan yang tepat terhadap pertumbuhan dan perkembangan anak usia sekolah sehingga menciptakan perkembangan anak yang baik dan terhindar dari gangguan jiwa ${ }^{6}$.

Berdasarkan paparan diatas maka dapat dikatakan bahwa Status sosial ekonomi adalah tidak mutlak memberi efek terhadap proses perkembangan anak, banyak faktor yang turut menentukan terhadap optimalnya proses perkembangan pada anak. Jadi tidak semata mata dilihat dari tingkatan atau kedudukan seseorang yang didasarkan pada kemampuan untuk memenuhi kebutuhan hidup sehari-hari dari penghasilan yang di dapat dan kelompok Status sosial ekonomi di masyarakat yang bertingkat dengan beberapa nilai-nilai kemasyarakatannya seperti pekerjaan, pendidikan, sumber daya ekonomi, kekuasaan dan informasi.

Banyak faktor yang mempengaruhi pertumbuhan dan perkembangan anak. Secara garis besar 2 faktor yaitu faktor dalam atau faktor internal dan faktor luar atau faktor eksternal ${ }^{7}$. Sedangkan ada juga yang membaginya menjadi faktor endogen dapat berupa faktor genetik, ras, keluarga, umur, jenis kelamin, kelainan kromosom dan Faktor eksogen dapat berupa faktor prenatal (Gizi, mekanis, toksin, infeksi, psikologi ibu, kelainan imunologi), faktor persalinan, faktor pasca persalinan (gizi, kelainan kongenital, lingkungan fisik dan kimia, sosial ekonomi, lingkungan pengasuhan, stimulasi, obat - obatan) ${ }^{7}$. 
Untuk riwayat persalinan pada penelitian ini lebih dari $55 \%$ memiliki riwayat persalinan normal dan sisanya dengan riwayat Caesar atau tindakan lain. Faktor persalinan juga dapat berpengaruh terhadap proses perkembangan anak. Sejalan dengan pernyataan Andriana yang menyatakan bahwa faktor persalinan yang merupakan bagian dari faktor eksogen yang merupakan salah satu faktor resiko terhadap proses tumbuh kembang anak ${ }^{8}$.

Sebagian besar responden 83,3\%memiliki Berat Badan Lahir Normal. Berat badan lahir rendah dianggap sebagai faktor risiko yang kuat untuk keterlambatan perkembangan motorik ${ }^{10}$. Bayi BBLR rentan terhadap abnormal tanda - tanda neurologis, koordinasi dan reflex, karena komplikasi neonatal yang menyebabkan perkembangan defisit motorik dan penundaan pada anak yang menunjukkan gangguan motorik yang akan mempengaruhi fungsi tangan dan kinerja sekolah mereka ${ }^{8}$.

Untuk Variabel Penyakit kronis yang pernah diderita anak seperti tuberculosis TB paru, hepatitis, kelainan jantung dan kanker juga merupakan sebagai faktor risiko yang kuat erhadap proses tumbuh kembang, karena jika seseorang mengalami infeksi kronis maka dibutuhkan asupan yang lebih guna memperbaiki situasi tersebut, yang pada akhirnya jika asupan pada anak kurang maka dipastikan berpengaruh terhadap proses tumbuh kembang anak termasuk keterlambatan perkembangan motorik ${ }^{9}$.

Menurut Susanto salah satu aspek perkembangan anak yaitu perkembangan sosial yang merupakan pencapaian kematangan dalam hubungan sosial ${ }^{11}$. Perkembangan sosial anak sangat dipengaruhi oleh proses perlakuan atau bimbingan dari orang tua terhadap anak dalam berbagai aspek kehidupan sosial, atau norma - norma kehidupan bermasyarakat serta mendorong dan memberikan contoh kepada anaknya bagaimana menerapkan norma - norma ini dalam kehidupan sehari hari $^{10 .}$.

Secara genetis, beberapa anak cenderung terpengaruh terhadap kondisi lingkungan tertentu. Faktor lingkungan memegang peranan penting dalam perkembangan anak. Begitu pula status sosial ekonomi orang tua. Anak yang hidup dalam ruang lingkup keluarga yang berpenghasilan lebih sedikit memiliki potensi lebih besar untuk mengalami resiko sakit, luka-luka, bahkan kematian dari pada keluarga yang berpenghasilan tinggi. Bagi keluarga yang ekonominya tergolong kurang mampu mereka tidak menjadikan kesehatan anak sebagai prioritas utama dalam hidup mereka karena untuk kebutuhan sehari-hari saja seperti makan dan sebagainya mereka harus rela menjemur diri di bawah sinar matahari agar bisa bertahan hidup. Kondisi tersebut menyebabkan kurang diperhatikan aspek kesehatan apalagi proses tumbuh kembang anak.

Proses persalinan spontan mengakibatkan bayi secara aktif mengalami reflek lahir yang tidak dialami oleh bayi yang dilahirkan secara caesar, dalam hal ini akan mempengaruhi proses pembentukan kognitif gerak (intelegensi praksis), dan kognitif bahasa, baca, tulis, hitung (representatif intelegensia) karena proses perkembangan awal dimulai dengan mekanisme 
refleks sebagai proses stimulasi dasar untuk maturasi otak ${ }^{11}$.

Penjelasan terkait kondisi diatas dikarenakan proses tumbuh kembang anak merupakan proses yang berlangsung sesuai dengan tahapan tumbuh kembangnya, sehingga bagi anak dengan riwayat persalinan Caesar/tindakan lain yang tidak mendapatkan stimulus atau replek lahir dapat tumbuh dan berkembang sesuai dengan tahapan perkembangannya, karena banyak faktor yang berperan dalam proses tumbuh kembang anak.

Penelitian Nazi dengan judul hubungan riwayat berat badan lahir rendah dengan perkembangan motorik halus. Penelitian ini menggunakan metode kohort prospektif dengan responden sebanyak 32 anak, hasil penelitian ini telah menunjukkan bahwa terdapat perbedaan yang signifikan antara kelompok bayi BBLN dan BBLR, yaitu keterampilan pada anak dengan riwayat BBLR cenderung terhambat. Nilai $p$ yang diperoleh yaitu 0.007 , artinya ada hubungan antara riwayat berat badan lahir dengan perkembangan motorik anak ${ }^{11}$. Namun demikian masih ada anak dengan riwayat berat badan lahir normal yang perkembangan motorik halusnya suspek sebesar 6 orang $(10 \%)^{12}$.

Kondisi tersebut mungkin disebabkan oleh berbagai faktor lain yang mempengaruhi proses tumbuh kembang anak, sehingga semuanya tergantung terhadap seberapa banyak anak menerima stimulasi-stimulus pada proses perkembangannya.

\section{KESIMPULAN}

Kesimpulan dari penelitian yaitu $60 \%$ responden adalah berjenis kelamin laki-laki, 23,3 \% responden dengan status sosial ekonomi orang tua kategori kelas rendah, 56,7\% responden dengan riwayat persalinan normal, 83,3 \% responden dengan badan badan Lahir normal, $100 \%$ responden tidak pernah menderita penyakit kronis $86,7 \%$ responden dengan tingkat perkembangan normal, tidak ada hubungan yang bermakna antara Jenis kelamin dengan tingkat perkembangan anak Usia dini di sekolah alam Indonesia Palembang Tahun 2019 dengan nilai $p$-Value $=0,511$, tidak ada hubungan yang bermakna antara riwayat persalinan dengan tingkat perkembangan anak di sekolah alam Indonesia Palembang 2019 dengan nilai $\quad p$-Value $=0,773$, tidak ada hubungan antara berat badan lahir dengan tingkat perkembangan anak di sekolah alam Indonesia Palembang 2019 dengan nilai $p$-Value $=0,337$.

Ada hubungan yang bermakna antara status sosial ekonomi orangtua dengan tingkat perkembangan anak Usia dini di sekolah alam Indonesia Palembang Tahun 2019 dengan nilai p-Value $=0,001$, Terkait Status social ekonomi yang berhubungan dengan tingkat perkembangan, baik pihak pendidik maupun orang tua harus mengetahui dan paham betul bahwa tingkat perkembangan anak bukan hanya ditentukan oleh single factor, banyak factor yang turut berperan langsung maupun tak langsung.

\section{SARAN}

Diperlukan penelitian lanjut terhadap pengetahuan dan kemampuan orang tua dalam mengenal secara 
dini tanda dan gejala dari gangguan perkembangan pada anak, sehingga meninimalkan kerusakan yang lebih permanen pada anak.

Diupayakan implementasi aktivitas Belajar dapat menstimulus dan mengevaluasi terhadap kemampuan anak terkait tingkat perkembangannya

Selain itu pihak sekolah dan orang tua sebaiknya bekerja sama dengan Unit Pelayanan Kesehatan (Puskesmas) dalam upaya memantau perkembangan anak dengan instrument DDST II

\section{DAFTAR PUSTAKA}

1. Dody H., (2017,7 Agustus). Indonesia Peringkat 101 Dunia Tumbuh Kembang Anak. Diakses pada 18 Maret 2019 dari http://paud.kemdikbud.go.id/2017/08/07/ indonesia-peringkat-101-dunia-tumbuhkembang-anak

2. https://www.bps.go.id/statictable/2010/03/19/ 1525/indikator-pendidikan-1994-2019.htm

Diakses pada 18 Maret 2019

3. Khaeruddin. (2009). Konsep Sekolah Alam Untuk Anak Usia Dini.

4. Susilaningrum, N. U. (2013). Asuhan Keperawatan Bayi dan Anak Edisi 2. Jakarta: Salemba Medika.

5. SR Diniyyah dkk, (2017). Asupan Energi, Protein dan Lemak dengan Kejadian Gizi Kurang pada Balita Usia 24-59 Bulan di Desa Suci, Gresik, Diakses pada 20 Juni 2020 dari https://ejournal.unair.ac.id/AMNT/ article/download/7139/4390
6. D. Istiana., (2016). Terapi Kelompok Terapeutik Anak Dengan Orang Tua Dan Guru Meningkatkan Perkembangan Mental Anak Usia Sekolah, Diakses tanggal 20 Juni 2020 dari https://e-journal. unair.ac.id/JNERS/article/download/3971/268 3

7. Chamidah A.N., 2009. Deteksi Dini Gangguan Pertumbuhan dan Perkembangan Anak. Jurnal Pendidikan Khusus. 5(2) : 84, 89,92

8. Andriana D., 2011. Tumbuh Kembang dan Terapi Bermain Anak. Jakarta:Salemba Medika.

9. Nazi S., 2012. Fine Motor Development of Low Birth Weight Infants at the Corrected Aged of 8 to 12 Months. Iranian Rehabilitation Journal. 10(16) : 22

10. Chaves R., Jone A.B., Games T., Souza M., Pareira S., dan Maia J., 2015. Efffects of Individual and School-Level Characteristucs on A Child's Gross Motor Coordination Development. Int. J. Environ. Res. Public Health. $12: 88845$

11. Susanto, A. (2011). Perkembangan Anak Usia Dini : Pengantar dalam Berbagai Aspeknya. Jakarta : Prenada Media Group.

12. Takarini, N. 2013. Pendekatan Terkini Brain Stimulation dan Brain Restoration pada gangguan neurologis anak. Makalah Seminar dan Workshop Nasional Fisioterapi. 2-3 November 2013. Hotel Orange Surakarta. Politeknik Kesehatan Kemenkes Surakarta. 